\title{
18
}

\section{IDEAS OF SELF-DEFINITION AMONG ZOROASTRIANS IN POST-REVOLUTIONARY IRAN}

\author{
Sarah Stewart
}

$T^{1}$ he tumultuous events of the Islamic Revolution of 1979 in Iran, followed by the eight-year war with Iraq, had a profound effect on the lives of all Iranians. Research conducted inside Iran on religious minorities during this time all but ceased. Moreover, the renewed religious fervour that characterized the post-revolutionary years in Iran, together with the continuation of discriminatory legislation, meant that many members of minority communities became reticent about discussing their religion - especially with foreigners. Information about the Zoroastrian retigion and its people in Iran over the past 40 years has thus been fragmentary and is derived from a variety of sources. There are the accounts of those who left the country after the Revolution and settled elsewhere, some of them returning regularly to visit family members, maintain property that they continue to own, and to do business. There has also been a growing interest, amongst young Iranian students and scholars, in the languages and cultures of pre-Islamic Iran. City dwellers - particularly the younger generation - use the internet with enthusiasm, and their websites and blogs provide insights into religious and social life, as well as the ways in which young Zoroastrians create and consolidate identities.

In the past two decades, researchers from institutions both inside and outside Iran have had greater freedom of movement within the country and better access to minority communities than in the early post-revolutionary period. ${ }^{1}$ Studies focusing on Zoroastrians and Zoroastrianism, in both rural and urban settings, include one undertaken by myself between 2007 and 2012, which included the recording of some 300 interviews with Zoroastrians from all walks of life in six main locations across Iran. ${ }^{2}$ Its context is that of the teachers, religious texts and community leaders from which Zoroastrians have gained their knowledge and understanding of their religion, as well as the literatures, histories and political circumstances that have influenced their ideas. The interviews provide the primary source of information for this chapter, in which I shall both look at the ways in which Zoroastrians have adapted 
to change over the past 40 years and also consider the ideas of self-definition that have developed as a result. It will be seen that these ideas have often been moulded by new phenomena, events or circumstances while at the same time remaining anchored to the past of familial memories, dreams, locations, histories and traditions.

Today one will find only a pale reflection of the village Zoroastrianism that was described by Mary Boyce and Michael Fischer in their ethnographic studies, undertaken in the 1960s and 1970s respectively. Yet religious life continues and is clung to tenaciously. Likewise, in the cities, Zoroastrians preserve their distinctive identity and continue to observe their festivals, adapting the performance of rituals to suit their circumstances. In many cases families return to their ancestral homes in the villages around Yazd to perform these in a more traditional way than is possible within city limits. So what does it mean to be a Zoroastrian in Iran today and how do Zoroastrians form their distinctive identities that distinguish them from their fellow Iranians? This question will be discussed within the framework of three further questions, the first of which is:

\section{How have Zoroastrians in Iran negotiated their minority status in order to practise their religion and survive as a comimunity?}

Here I consider some of the structures in place at national level that govern Zoroastrian minority status; I also look at the ways in which internal matters within the community are managed through organizations such as anjomans and the Mowbedan Council.

Until the adoption of theconstitution in 1906, individuals such as Maneckji Limji Hataria, the Parsi agent who secured the temporary lifting of the jezyeh or poll tax, had negotiated improvements in conditions for minorities on a personal level. Under the new constitution, Zoroastrians were able to send a deputy to represent their interests in parliament, a development which gave them a formal structure within which to operate and which marked the beginning of recorded proceedings. ${ }^{3}$ The collective memory of community history before this time is based on oral traditions rather than documentation. The twin pillars of internal governance, lay and priestly, together with the wealth generated by the growth of the Zoroastrian population in Tehran from the late nineteenth century onwards, began a modernization process with which Zoroastrians are familiar, a process that is often recalled within the context of family history. Those who have achieved a certain prominence within the community, both today and within living memory, are often referred to in interviews. The knowledge that they belong to the Zoroastrian community alone reinforces the sense of identity; through such people the successes and setbacks of the community can be charted.

An example of such a distinguished individual is the high priest, Mowbed Rostam Shahzadi (1912-2000), who was one of the four representatives of 
minority religions debating the new constitution of the Islamic Republic of Iran after the Revolution of 1979. Mowbed Shahzadi fought hard for the rights of Zoroastrians and was overtly critical of the wording of Article 13 of the Constitution, which refers to Zoroastrians, Jews and Christians as minorities. He felt strongly that Zoroastrians belonged to the land of Iran and its people and shared many cultural traditions with their Muslim fellow countrymen. ${ }^{4}$ Since Shahzadi's time, the onus to push for amendments to legislation and to seek equal rights for Zoroastrians in law has continued to fall on the Majles representatives, whose strong identification with the history, culture and land of Iran still seems to set them apart from other minority representatives. Parvis Malekpoor, twice Deputy to the Majles, was another outspoken Deputy who replaced Mowbed Shahzadi in the Majles at a time when there was a confrontation between conservative and liberal-minded Zoroastrians over who should control the Tehran Zoroastrian Anjoman. In a long interview he described in some detail his campaign to become a member of the first National Parliamentary Assembly, Majles-e Showrā-ye Eslāmi, formed after the drafting of the constitution, which brought him into direct competition with Mowbed Shahzadi, for whom he none-the-less had great respect. Malekpour was deeply critical of the judicial system's inabilifyto prevent the harassment of Zoroastrian schoolchildren that was occurringduring his term of office:

The issue involving education began when some people, and I do not know how to describe them, found excuses to harass the children and young people. We did our best to prevent and put an end to these harassments. In the Majles I was the first member who criticized and complained about the nascent judicial system in the country; you can find the proceedings in the Majles too. This caused noise in the Majles and Mr Ayatollah Sādiq Khalkhāli (1926-2003) [the notorious chief justice of the Revolutionary Court] actually [verbally] attacked me. I think in those days, honestly, had it not been for Hāshimi Rafsanjāni [and his protection] I would probably not have managed to lead a sound and healthy life (jān-e sālem be dar nemibordam)!

Today the Zoroastrian Deputy to the Majles is Dr Esfandiar Ekhtiary, a businessman from Yazd, who continues the struggle to obtain equal status in law for Zoroastrians with respect to long-standing issues such as that of inheritance. ${ }^{5}$ In his address to the Majles after the Nowruz holiday in 2014, he drew attention to Articles 13 and 3 of the constitution that call for freedom, equality and judicial stability for all Iranians. He asked President Hassan Ruhani to ensure that these be observed. Further, he addressed the amendment to Article 881 of the Civil Code that repeals the rule that a non-Muslim cannot inherit from a Muslim, inquiring why in six years this had not been implemented by the judicial committee of the Majles. ${ }^{6}$

Articles that discriminate against religious minorities have remained unmodified in the Penal Code with respect to a number of offences including adultery, homosexuality and pre-meditated murder. ${ }^{7}$ Article 297 in the penal 
code deals with the diyeh or blood money payable to the family when the victim of a death by murder or manslaughter (as happens for example in a car accident) is a non-Muslim. The compensation calculated for a non-Muslim (male or female) is the same as for a Muslim female, which is half the amount awarded to a Muslim man. An amendment to this article whereby the diyeh payable to Muslim and non-Muslim men be equalized has not yet been implemented in law.

Whereas there are punishments exacted for the violation of the corpse of a Muslim, there are none stipulated for similar crimes against a deceased Zoroastrian. This finds resonance in several of the interviews where it has been mentioned that bodies were routinely removed from the dakhmeh for the purposes of medical research. The desecration of the dakhmeh is the reason frequently given for the abandonment of the system of exposure of the dead some 35 years ago.

Zoroastrians rely on their community anjomans and the Shorā-ye hall-e ekhtelāf-e Zartoshtiyān, 'the council of elders to resolve Zoroastrian conflicts' as far as possible without recourse to Islamic courts. The central Tehran Anjoman is an umbrella organization for 26 local anjomans, most of which are in Yazd province. In addition to looking after social welfare, the anjoman acts as a bridge between the Zoroastrian communities and the Islamic government both at local and national level. It preserves the traditional heritage of Zoroastrians and spends much of its time, at local level, managing endowments and the communal funds for festivals and the upkeep of community halls, shrines, cemeteries and fire temples. It interprets and applies Zoroastrian law (as enshrined in the Personal Status regulations for Zoroastrians) concerning important matters such as inheritance, adoption and divorce. The anjomans keep the register of marriages, deaths and other records and its archives are the only accurate collective memory of the community. Much of the work of the anjoman in Tehran has to do with land requisition and fighting cases against various government ministries; these can be protracted affairs with no end in sight. ${ }^{8}$

In addition to the Tehran Zoroastrian Anjoman an organization called the Sāzmān-e Farvahar was founded in 1960 for the purpose of addressing the needs of young people - it was felt that the Anjoman was rather old-fashioned - and so social and cultural events were organized as well as seminars on religion, and athletic, artistic and leisure facilities were established. Since the Revolution the Sāzmān-e Farvahar has taken responsibility for charitable works, such as supporting the families of those who lost sons in the war with Iraq, those who were freed prisoners of war and those affected by natural disasters. It also ensures that Zoroastrians mark the special days in the national calendar of the Islamic Republic, for example 11 February, a National Holiday held in commemoration of the Revolution.

The Mowbedan Council or Kankāsh-e Mowbedān-e Tehrān, which addresses the needs of the mowbeds and mowbedzädehs, provides religious education 
for the community and continues the tradition of answering their questions about the religion. Sessions are led by the Mowbed Mowbedān, Dr Ardeshir Khorshidian, and many of the debates are incorporated into one or other of the leading Zoroastrian websites in Iran, Amordadnews and Beresad. These websites bring the relationship between the government and the Kankāsh, concerning religious matters, into the public domain. Questions put to the Kankāsh often have to do with community rules. A recent session, for example, concerned the mehriyeh, the payment of an agreed sum of money by the husband to his bride-to-be, the payment of alimony following divorce, the rules pertaining to child maintenance and the age when an adolescent is considered an adult in the eyes of the Zoroastrian religion. The questioner is reminded that the constitution of the Islamic Republic of Iran requires religious minorities to abide by their own personal status laws Articles $21-37.9$ Here it is stated clearly that divorce is not an option in the Zoroastrian religion, which is why the payment of mehriyeh is not included in the marriage contract. If, however, there is sound evidence to prove one or other of the exceptional circumstances listed in the Personal Status, then the marriage may becterminated.

Sometimes the Kankāsh is asked to respond to the government on religious issues. For example, the Ministry of Islamic Culture and Guidance asked that Zoroastrians cease performing the Shāh-Pari Söfreh. ${ }^{10}$ The problem arose over whether the name should be associated with the evil pairikas, who are servants of Ahreman, or with Paridon (Avestan Thraetona and Persian Faridun), who is associated with healing. The Muslim view was that of the former association. The Kankāsh refused to back down and responded:

Setting up a sofreh communally, performing rites, gatherings, social intercourse, merrymaking, cooperation? communal feasts and happiness are all good/acceptable customs which answerthe needs of the community both socially and psychologically. For this reason the Anjuman-e Mowbedān of Tehrān in no way objects to the practice of setting up sofrehs and it regards them as commendable. Each and every day in the month of the Zoroastrian calendar is dedicated to a cherished name belonging to a Yazata (Izad) and the followers of the Good Religion (behdinān) choose a day or a few days belonging to Yazatas during the month. They set up sofrehs, get together communally and cooperate together.

In both responses the members of the Kankāsh achieved a balance by demonstrating the differences between Zoroastrianism and Islam, whilst taking care not to allow the religion appear too alien.

There are 60 priests in Iran today of whom eight are female. ${ }^{11} \mathrm{~A}$ few are hereditary and the majority are part-time. The fact that mowbedyārs, 'non-hereditory priests', are not permitted to perform the full rituals means that these have been shortened - the full Yasna for example is no longer performed. Only two priests were interviewed, both full mowbeds, who recite the nightlong Vendidad. Despite their diminished role as ritual specialists, priests are still expected to undergo rigorous training in the correct pronunciation of 
the Avestan language and the quality of recitation is considered to be very important. A Tehrani Zoroastrian lady makes this very clear:

A good mowbed needs a good voice. His voice must attract attention. As we say, his mantra must hold you. Some people say that while listening to the Avesta they fall asleep ... They say look, the mowbed is reading the Avesta and so and so has fallen asleep. I do not think this is bad at all. It shows that the mowbed who is reading the Avesta is reading it so beautifully that even though the person listening has just lost a loved one he is so comforted that he falls asleep. This signifies the power of that mowbed who is reading the Avesta with such a nice voice. Then there are mowbeds who once they are done you want to slap them in the face. His voice is so bad and he reads the Avesta so badly that he makes you quite nervous. But I see the role of the mowbeds as very important.

The relationship between Zoroastrian doctrine and the lived experience of the religion that is brought to life via interviews is a product of priestly teaching and should be viewed within the Iranian context. Scholar-priests of the twentieth century, such as Mowbeds Firouz Azargoshasb (1912-96) and Shahzadi, who were both trained in India, became very influential within the Iranian Zoroastrian community. Their translationsof the Gāthās from Avestan into Persian are those most in use today by the laity in Iran and derive mainly from the work of the scholar Ebrahim Pourdavoud (1885-1968), who in turn acknowledged the influence of Western scholars of his generation such as C. Bartholomae, L. H. Mills and K. F. Geldner. ${ }^{12}$ Priestly discourse in Iran is also informed by Persian literary traditions. In a sense one could say that the teaching of Zoroastrianism in Iran is partly defined by the quest for historical continuity within the Iranian literary tradition. The public lectures delivered by Shahzadi in 2004 are representative of views expressed today. They are noteworthy for the way in which Shahzadi draws on situations in daily life and cites Persian literary works with which his audiences would have been familiar. The following passage is from a lecture devoted to the subject of dualism:

the ancients had wondered how can day and night, which are so different from one another, have been created by one creator: night must have been created by the god of darkness and day by the god of light and happiness. How is it possible for rose and thorn to have been created thus? When we reach out to pick the beautiful rose, which emits its sweet scent, should our fingers touch its thorns and be injured? The one who has created the thorn, they had thought, must be an enemy of human beings, who does not wish us humans to reach and hold flowers. How is it possible that a god should give us our lives, and the same should take them away from us? They would say, no, there have to be two gods, one responsible for goodness and the other the god of wickedness. However, as I have mentioned, 3,733 years ago a Prophet appeared in this world for the first time and stated that all has been created by Him. Yet, when you view the world with your own eyes, you perceive things differently [...] Asho Zartosht has stated that what we regard as good is attributed to spènta mènō, and what we perceive as wickedness and ugliness is an attribute of ayra mènō. 
It can be seen here that while Shahzadi espouses the strict monotheism of Pourdavoud's interpretation of the Gäthās, he nevertheless conveys a sense of dualism in the dichotomies he describes. In general, priestly teaching reflects a coalescence of ideas drawn from a variety of sources. When Western academic interpretations collide with the 'traditional' understanding of doctrinal matters this often results in debate within the community and a defence of the indigenous view.

2 What makes Zoroastrians stand apart from their fellow Iranians and what are the shared identities that separate them from Zoroastrians outside Iran?

Apart from religious beliefs there are a number of cultural differences that distinguish Zoroastrians from their fellow countrymen. These include language, religious education, issues to do with mixed marriages and emigration as well as religious observances, festivals and shrines. The distinctive Dari dialects, which Zoroastrians maintained from earlier times in order not to be understood by their Muslim conquerers, are still spoken today. There were two main Dari dialects spoken by Zoroastrians, one in Yazd and another in Kerman, as well as a number of sub-dialects within the Yazdi dialect belonging to certain villages. ${ }^{13}$ While these are dying out as villages are abandoned, they are still spoken by Zoroastrians wherever they have relocated. For example, Zoroastrians from Taft will speak the Tafti Dari dialect even though they are living in Tehran.

Religious education for religious minorities became more clearly defined after the Revolution. Whereas Zoroastrian children used to be sent home on Fridays, when religious education classes were held for Muslim children, after 1979 it became compulsory for alb children to receive religious instruction, including those belonging to religious minorities. This development caused a major shift from home teaching to the classroom and meant that knowledge about the religion was no longer dependent on family members - although prayers were still learned at home from an early age. Some interviewees expressed the opinion that the religious fervour that accompanied the Revolution actually promoted a greater sense of religiosity amongst Zoroastrians. A priest in Tehran explained that his religious activities began after the Revolution:

That was a change, which really affected our community in terms of its religion [...] that because the country had changed from being secular to being deeply religious that everyone should do their bit [...] I was 30 and I started in earnest and have continued ever since. I have never left my job to work as a full-time priest, but I became very involved [...] Even the children would not have observed their religion had it been the continuation of the previous regime. Because then it was very lax - I could even say that religion was discouraged. There were many incentives not to be religious, and many attractive activities that you would prefer to being religious.

Asked whether he thought this was a good thing, he replied: 
In this way of course; in this way we are all really indebted to this Revolution! Not only the elders, but the children too. Those who were seven years old not only had to start religious classes but their eyes opened, really opened. And then everything became religious, the radio and the mass media. And the feeling of wanting to be religious came naturally.

Others have expressed this view rather differently, pointing out that in order to counter the focus on Islam, it became necessary to ensure that the Zoroastrian religion was kept alive and of importance to its followers.

There has been a revival of interest in the Avestan language amongst young Zoroastrians, which is witnessed in the growth in popularity of an Iran-wide Avesta competition that has been an annual event since 1994. This is characterized by a focus on the correct recitation of Avestan texts and an emphasis on meaning rather than ritual. It appears that today young people prefer to interpret the practices described by Mary Boyce ${ }^{14}$ within the context of village life in times gone by, and offer practical reasons for the previous existence of purity laws and such institutions as the dakhma system. It is not possible to know from Boyce's account whether or not the people who engaged in these practices made the same doctrinal connections as she did. Certainly today those living in Sharifabad and other outlying villages appear largely unaware of doctrines as they are usually known from the classical tradition: their knowledge is confined to what they term the Avesta, which consists of the Gäthās, the Yašts, Vendidad and Visperad, and the Khordeh Avesta. Texts such as the Bundahišn are deemed mythological' in the sense that they are thought of as stories that belong to a later tradition and were developed as a means by which to explain the teachings of the Zarathustra. As such they are not considered authoritative in the same way that the Avestan texts are. When asked whether he believes in the Zoroastrian story of creation, a priest from the village of Narsiabad reflects:

If we look at the spiritual side of these stories they are the presence of good and evil in the mind. If you remove the dirty things from a room the room is clean. Same with men. If you take away the bad things from people's minds then they will become good. So in a sense, the Bundahishn it is a metaphor for the good and evil in men's minds. The books written after the Gāthās were written by the followers of Zarathustra. They are interpretations not the words of the prophet, so we do not know how correct they are.

Many belonging to the older generation, on the other hand, reflect the more traditional attitude to prayer:

I do not think we read our prayers in order to make sense of them or understand them. If the intention was to understand the prayers, we would have composed beautiful and meaningful phrases in praise of the God and recite them constantly. These ancient niyāyishes contain within them a timeless and sacred spirit; once they 
are translated that spirit which is contained therein dies away and disappears. If one reads the Ätash Niyāyish or Ābān Niyāyish in translation, one does not gain anything from them, whereas the ancient texts do have an effect - we do not read niyayishes for their meanings, but rather for their spiritual/psychological effects.

Issues that affect the Zoroastrian community, and which in a sense are linked to each other, are those of intermarriage and emigration. The question of intermarriage is influenced by inheritance laws - which heavily favour the family of the convert to Islam - as well as the fact that proselytization is considered a capital offence. As might be expected, those living in rural areas tended to be more conservative in their outlook than those who live in Tehran. None the less it was a Zoroastrian gentleman in Tehran who declared:

In such cases, I think, parents must have been negligent in properly raising their children [...] It is the parents who are to be blamed. If such a thing happens nowadays not much can be done to prevent it, I am afraid, prevention might make it even worse. Zartoshti children must be instructed from an early age not to consider marriage outside the religion, just as other religions discourage this as well. The problem is also related to our society: isolation and limited interaction between opposite sexes causes this; a young boy, for instance, is at work and meets an attractive, non-Zartoshti girl, or vice-versa, and the result is obvious. In my opinion, it doesn't make any difference if the non-Zartoshti boy or girl actually expresses his/her interest in learning about and/converting to our religion, since (s)he has not been raised in the culture. The result, of course, will be to sever their relations with both families completely. Imagine if a Zartoshti boy marries a Muslim girl, and then realizes that the girl's uncle is a Muslim fundamentalist/member of the establishment (hezbollāhi); should or could the girl cut off her relationship with her uncle? The couple may tolerate their differences and live together but they cannot truly love one another family unions are very important and effective in this regard, theirs will remain awkward, strange, and eventually dysfunctional.

Older people seem generally more sympathetic to the needs of young people and their desire to seek better job opportunities abroad, but they often express doubts about young people's ability to resist a wholehearted adoption of Western culture. The following view from an interview with a Zoroastrian in Ahwaz sums up the two arguments:

Emigration has to be examined from two perspectives: one has to do with responsibility and the other with practicality. From the responsibility perspective, we are the inheritors of an ancient culture and the way we are going, unfortunately, I do not think that after one or two generations we will have more than a few people left belonging to our religion, and our base will disappear from this world. Those who emigrate, no matter how strong they are, they can only keep one or two generations culturally intact $[\ldots]$ From this point of view, we have a responsibility towards our ancestors and our descendants and we should therefore not emigrate. But if we look at it from the point of view of living conditions, and bearing in mind the social 
conditions presently prevailing in our country, and remembering the limitations Zoroastrians and other minority groups face - these exist and no one can deny them [...] For those that have no future here, especially financially, because of the political, economic and social problems that exist within our society, they are committing a crime against their children if they stay here. If they emigrate they will be sacrificed but their children will have a better life.

Popular religious observances include those that accompany the six great seasonal festivals, and the gāhāmbārs and jashans that are endowed for particular reasons such as in memory of the deceased, or to honour a vow. These are exclusively Zoroastrian affairs and accompanied by prayers and foods specially prepared for the occasion. The controversial subject of animal sacrifice still causes polarized debate - mainly among Zoroastrian communities outside Iran. It is, however, possible simply to view it as the traditional way in which farming communities provided (and still provide) a communal meal. It is the way meat is provided, for example, during the festival of Mehragan that is still celebrated in the Yazdi villages of Zeinabad, Mobareke and Cham between 31 January and 4 February according to the Qadimi calendar. ${ }^{15}$ The festival is often dedicated to someone who has passed away and is described thus:

During the jashan of Mehr-izad, which is the first of the jashns in [the month of] Mehr [...] during the first year [after the passing of the deceased] - they would kill a sheep and roast its meat. They would Serve it with komāj and halvā, bread and sabzi (fresh greens). They would pull the meat, place it on the bread, next to komāj and halva and sabzi too, with some siräbi (stewed offal), and these would be sent to the neighbours' and relatives' houses. This was done during the day of Mehr-izad in the month of Mehr, and thiswas repeated for three years. Others would kill the sheep, chop the meat and distribute it raw to others. (Muslims)

The identities shared between Zoroastrians and non-Zoroastrians develop from certain popular devotional practices, oral traditions and historical events. As such they are essentially Iranian and, although also part of life in the diaspora, are more strongly felt inside Iran. The cult of shrines and votive sofrehs, usually performed by women, are two areas of popular devotion shared by Muslims and Zoroastrians. While the Zoroastrian shrines have different theological underpinnings from Islamic shrines, the fact that they are largely absent in India or the diaspora (unless one includes the domestic shrine, or altar, that exists in all Zoroastrian homes) suggests that they derive from Iranian culture and are rooted in the pre-Islamic past. Zoroastrian shrines include the six main pilgrimage centres all of which are located in Yazd province and are referred to as pir-e bozorg. They are associated with legends of the last Sasanian king, Yazdegird III, and his family and their flight before the invading Arab armies. There are a large number of shrines that are attached to a local narrative that is connected to a supernatural event or vision - usually a dream. 
Shrines associated with a particular natural element, such as a great tree, are often endowed with the capacity to grant a wish. Finally, there are those that commemorate an event or a person. These may be no more than a niche in the wall of a street. The story of Master Khodabakhsh, in the Mahalleh of Yazd is such an example. Master Khodabakhsh was employed as a teacher in the school founded by the Yazdi merchant, Kei Khosrow Sharokh. He was assassinated in 1918, apparently for his liberal views gained during a sojourn in India, his use of the fasli calendar and opposition to animal sacrifice. He was also accused of being sympathetic towards Bahaism. The place where he died is marked by a small shrine. ${ }^{16}$

Votive sofreh rituals are generally considered marginal to mainstream orthodoxy in both Muslim and Zoroastrian communities, partly because of the dubious identity of the supernatural beings to whom they are dedicated and also because of the idea that a votive offering, such as the sacrifice of a black hen, can result in the granting of a wish. There is also the fact that they are outside the remit of priests and the control and supervision of men more generally. ${ }^{17}$

In the category of shared identities is the body of Persian literature that is beloved by all Iranians and Zoroastrians the world over, of which the most prominent work is the epic Shähnammeh, a text that has been influenced very little by Islamic ideas and is strongly rooted in Iranian traditions. ${ }^{18}$ In many of our interviews the Shähnameh is often referred to as part of early childhood memory - the stories being passed down orally, or read, in much the same way as the Avestan prayers were transmitted by family members to their children and grandchildren. For example:

Each year at Mehregān, my mother used to tell us the story of Kāveh the Blacksmith or if we were celebrating Tirgān, she used to tell us the story of Ārash. Stories that are mythical and traditional - we used to hear them. At night when she put us to bed, we would be told the story of Rustam and Sohrāb. The stories we heard as children differed from the fairytales other children were brought up on. As children we were raised on stories of the Shähnämeh.

Reminiscing about her childhood, a middle-aged lady in Kerman told us:

We had a fire-temple here of course, where students - mostly boys - would attend Shähnāmeh reading classes. It was similar to the maktab-khāne (traditional [Muslim] schools); my father, for instance, knew all the Shähnāmeh by heart [...] As a farmer he never developed his writing skills and was not a literate person, but orally he was amazingly well trained. He knew both the Shähnämeh and the [Divān of] Hāfez by heart. In winter when there was a lot of snow and farming was impossible, we all would gather together and my father would hold the Shāhnāmeh - they would have gatherings at each other's houses - and all would recite together. Whilst playing together the children would slowly become familiar with all these literary traditions and culture. 
Although the sense of Iranian identity can be seen as a factor that draws Zoroastrians in Iran to the non-Zoroastrian majority population, it should be noted that the latter are largely unaware of the pre-Islamic roots of much of their literary culture. Likewise, there are various cultural events and symbols that have become part of national Iranian identity, divorced from any Zoroastrian connotations. Nowruz is one such example, where it has now become customary for Iranians to flock to the tomb of Cyrus the Great at Parsargadae to watch the sun rise at dawn. The Persian haft sin seems likely to have derived from the Zoroastrian haft shin, or seven items beginning with the letter shin that are laid out at Nowruz by Zoroastrians in Iran. The fravashi has long been a national symbol in Iran but, although recognized to be a pre-Islamic symbol, is not associated with Zoroastrianism by the majority population. The Cyrus cylinder has become a symbol of human rights not only for Iran but also for the United Nations - again rarely, if ever, linked to Zoroastrianism.

More recently there has been another cause for shared identity, one which causes conflicting emotions when discussed, namely the Iran/Iraq war of the 1980s. While no Iranian Zoroastrians we have spoken to declare anything other than a willingness to fight for their country, Iran, the idea of martyrdom promoted by Ayatollah Khomeini as a reward for dying in battle has no resonance in Zoroastrian eschatological beliefs. Those who lost their lives in the war are recognized as martyrs by the state and this has given rise to an annual ceremony that takes place in the Yąd ārāmgāh. Performed by mowbedyārs in front of pictures of the young men who died, it serves as a reminder of their lives and the circumstances of their death.

3 What are the narratives that Zoroastrians draw upon to construct ideas of self-definition?

This question is linked to the body of oral literature from which Zoroastrians derive their sense of community history, and which is an important part of identity formation. A narrative that has remained in the collective memory of those who feel they belong or once belonged to a particular village or town often underpins that sense of 'place'. Certain events have become part of folklore in much the same way as the story of migration from Iran to India, as described in the Qesse-ye Sanjān, has for Parsis. These events form the basis for the stories that Zoroastrians tell themselves about themselves, which often describe a recovery or survival in the face of adversity. They are often formulaic and, as such, are not to be taken literally. Sometimes they are interwoven with dreams and/or conflated with stories attached to different historic events. The Afghan invasions of Kerman (1719-24), for example, identify Kermanis with their city and are recounted as part of a shared narrative. The fact that the Zoroastrian community was obliged to live outside the city walls meant that it invariably bore the brunt of the onslaught. ${ }^{19}$ Stories about these episodes have 
become part of the oral tradition of Zoroastrians living there today. Accounts vary in detail. Some accounts focus on the slaughter and devastation that required a makeshift dakhmeh to be built in order to lay the bodies of those Zoroastrians who were massacred at the city gates. Others tell of the various ways in which the surviving Zoroastrians managed to flee and make their way into the city via the underground qanät system, or by hiding in the well of Shāhverahrām Izad:

When Mahmood Afqān attacked Kerman, many Zoroastrians were killed; it was because they were living outside the city and out of the city gate. In Shähverahram Izad there was a well inside where some Zoroastrians hid, leaving their swords outside the well. Afqāns were Muslims and believed in the story of 'Ali and his sword. So the shrine of Shähverahram Izad remained safe and Zoroastrians took refuge there. ${ }^{20}$

The Zoroastrian population of Kerman is smaller than that of Yazd today and the Kermani Dari dialect rarely spoken. The villages gutside Kerman are no longer inhabited by Zoroastrians. ${ }^{21}$ In the opinion of one Kermani lady the demise of Kermani Zoroastrian agriculture was not because of a lack of water but because many young people moved to Tehran, leaving only the elderly who were no longer fit to farm. She explained that Yazdi businessmen had moved into Kerman during the time of Reza Shah and bought up agricultural and other properties. When asked if she was referring to the 'arbāb-e ra'yat', or struggle between farmers and landed gentry, she replied:

Quite. Yazdi arbāb ['landed gentry'] never married their daughters to the Kermani farmers and always tried to maintain and preserve the distinctions between the ranks. I know of so many stories pertaining to Zartoshti arbābs who treated their Zartoshti farmers most indecently and exploited them. No doubt they had ties with the English and had learnt how to exploit the poor. The majority of the arbāb were Zartoshti; they were not interested in the affairs of the peasants and never gave them a plot of land to improve their livelihood. Their children acquired some education, moved to Tehrān and thence to the U.S., leaving their houses and lands behind ... Then they [the government] confiscated plots of land from the landlords and distributed them amongst peasants [during the 'White Revolution' in 1960s]; and they [landlords] were very upset.

Another popular story involves the murder of a Muslim by a Zartoshti during the reign of the Safavid king Shah Abbas. The Kermani version the fatvā issued by the Ayatollah, entailed someone putting his fist into a jar of shireh (syrup) and then inside a jar filled with arzan (millet). However many seeds could be counted dictated the number of Zardoshtis to be killed by way of punishment for the murder. In the event, the king's mother dreamed of the impending massacre and averted the situation by ensuring that her son allowed only one death for the death of the Muslim. Fischer also narrates this story, but with 
reference to the founding of the Yazdi village of Nasrabad (Narsiabad) - an example of how oral traditions migrate from one location to another. ${ }^{22}$ In the Narsiabad version the seeds that stick to the syrup are not millet but opium. This detail finds resonance in another of the interviews, with a farmer from Narsiabad, who said that his grandfather had lived in a district known as Godal Thavab, which grew opium. Evidently Zoroastrians were responsible for collecting taxes for opium since government officials were reluctant to do so. The story is about a man who had opened his opium pods to collect the resin but overnight rainfall had ruined his entire crop and he was unable to pay his taxes. Eventually, after all sorts of misadventures, he ended up in the court of Nasruddin Shah and helped to unblock a qanat for which service he was rewarded with being exempted from the tax he owed. Such stories give a flavour of the oral history with which Zoroastrians identify themselves, and which vary depending on place and context.

The city of Ahwaz, in Khuzistan province, is very different from other cities and from the Zoroastrian villages of the Yazdi plain. Although it now has a population of only 97 Zoroastrians, this is an active community with an anjoman and dedicated mowbedya $r$, who likens it to a large family. The city was founded by Ardeshir I at the beginning of the Sasanian period, when it was known as Ohrmazd-Ardeshir. In modern times it is distinctive for three principal reasons: its oilfields, its high proportion of Arabic speakers (24 per cent), and the fact that it was the frontier province that Iraq attempted to annexe in 1980. The Zoroastrian population of Ahwaz has been affected by all three of these factors. Many work in the oil business and are generally entrepreneurial. They have good relations with their Arab neighbours, who themselves are treated as an ethnic minority by the Islamic government and who were also at the forefront of the war with Iraq. When asked which city he would prefer to live in, Tehran, Yazdor Kerman, the priest in Ahwaz, Mr Pooladi, answered:

With respect to political and social life in Iran, I prefer Ahvaz and like the attitude of non-Zoroastrians towards Zoroastrians; there is more freedom and they are more helpful. With regard to the Zoroastrian community, I believe the Mowbedan Council should give more help to Zoroastrians of Ahwaz in their religion.

This view is borne out by Mr Pooladi's father, who at the time of the interview was 86 years old. He related how his wife had been found for him through the prayers of a Muslim woman. He explained how this had come about, after first asking his wife to block her ears:

At the time I was a very fun-loving and handsome young man. Lots of girls were after me, but I was not having any of them. I had a friend in Ahvaz called Colonel Nusratullah Naghavi. We were friends. He was a Muslim and he had married a Muslim called Muluk Vahabi. Muluk's mother was a highly religious woman who would cover her face if there was a male fly in the room. One summer Muluk's mother $[\ldots]$ came to Ahvaz to stay with her daughter. I told them that I was going 
to Yazd to visit Pir-e Naraki. The Colonel, his wife and mother-in-law said they wanted to come too. It was summer. We went to Esfahan, and then Yazd, and from there we went to Pir-e Naraki [...] When it came to the time to say goodbye to the Pir, I was reading the Avesta when I saw the Colonel's mother-in-law come in and spread her prayer rug and put on her chador and start to perform her namaz. Afterwards they left for Esfahan and Ahvaz and I went to Yazd from where I intended to leave for Tehran. When I returned to Yazd I saw a lady standing at the end of our street. (He points to his wife). I asked who she was and let it be known that if she wanted to be my wife, I would like that. I took the bus and went off to Tehran. By and by we became engaged and some time later I went back to Ahwaz. The Colonel's wife said she wanted to make another pilgrimage to Pir-e Naraki. I asked her why and she said that when she was saying goodbye, she had asked the Pir to find a wife for me.

This short extract illustrates a view that often occurs in interviews, which shows that Zoroastrians invariably maintain a good relationship with their Muslim neighbours on a day-to-day basis. This is apparent mainly through anecdotes and stories that involve the resolution of a problem. When questioned directly about this relationship people tend to refer to an Kistoric event in which Zoroastrians have suffered at the hands of Muslims. Relations with Muslims at the local level are separate from those of the leaders of the Zoroastrian community who, as shown above, are engaged in constant negotiation with the State in order to try and equalize laws that are discriminatory and can make life intolerable.

The changes that have taken place within the Zoroastrian community since the establishment of the Islamic Republic of Iran can be summarized as having been due to two main factors: first, demographic changes as people move from the village to city and, second, the direct effects of the Revolution on religious life. Interviews show people's self-perception to be both resilient and resigned. Their resilience lies in their practical attitude towards the exigencies of life in Iran today; their resignation is in that they often express nostalgia for the past, and a desire to preserve religious customs. For example, they encourage their young people to seek better opportunities abroad but often in the hope that they will return.

Although the anjomans function in much the same way as they have always done; in the countryside much of their work nowadays has to do with legal disputes regarding land appropriation by the state; in the cities it has to do with unpaid rent for properties similarly requisitioned. The Mowbedan Council has assumed a more pastoral role, since priests no longer perform the full ritual ceremonies, nor are there any longer Iranian Zoroastrian institutions for priestly training. However, in spite of these facts, religious awareness has undoubtedly been enhanced by the increase in the religiosity of the general majority populace. Zoroastrian religious practice varies depending upon whether the community is rural or urban-based, and there are also differing views on emigration and intermarriage, ritual and doctrine. 
Events such as the Iran/Iraq war brought a very clear response from Zoroastrians who expressed an unwavering loyalty to the land of Iran, even though the concept of 'martyrdom' is contrary to Zoroastrian religious belief. Although numbers are indeed dwindling, it can be seen that the sense of Zoroastrian identity is steadfast amongst those who remain. The villages become populated at certain times of the year - urban dwellers return to their ancestral homes and some even continue to farm their lands. The regional Dari dialects are spoken amongst those who have moved to the city, and the study of Avestan continues.

\section{NOTES}

1. Most recently Michael Stausberg and Yuhan Sohrab-Dinshaw Vevaina, The Wiley Blackwell Companion to Zoroastrianism (Malden, 2015); Navid Fozi, Reclaiming the Faravahar: Zoroastrian Revival in Contemporary Tehran (Leiden, 2014); Richard Foltz, 'Zoroastrians in Iran: What future in the homeland', The Middle East Journal lxv/1 (2011), pp. 73-84.

2. This project, funded by the British Academy, was undertaken with Mandana Moavenat whose family in Tehran and Zeinabad facilitated the gathering of information over a number of years. Many of the interviews were conducted by Zoroastrian researchers, in particular a retired teacher and respected member of the Zoroastrian community in Yazd. This methodology enabled the interviewer to gain insights into religious and social life that an outsider would find difficult to obtain.

3. The Majles records give invatuable insight into the relationship between the Zoroastrian community and central government.

4. Eliz Sansarian, Religious Minorities in Iran (Cambridge, 2006), pp. 67ff.

5. See Foltz, 'Zoroastrians in Iran', pp. 77-8.

6. It is worth noting that according to the Zoroastrian Personal Status document, updated and approved by the Ministry of Justice in 2007, the amendment has been agreed. Article 31 states that when either husband or wife converts to another religion, thereby causing divorce, half the assets of the convert have to be given to the party who remains Zoroastrian. However, all Minority Personal Status regulations, despite being ratified by the government, are overruled by constitutional dicta whenever there is conflict.

7. If a Muslim man commits adultery with a Muslim woman he is subject to 100 lashes, but the death penalty applies in the case of a non-Muslim man. With respect to homosexuality, Article 121 states that a homosexual act between two Muslim men is punished by 100 lashes. Where the 'assertive' partner is a non-Muslim the latter is subject to the death penalty.

8. For example the case of Qasr-e Firozeh, the main ārāmgāh or burial site in Tehran, which began with the acquisition of land by the Tehran Zoroastrian Anjoman in 1935 and remains ongoing. See Sarah Stewart, 'The politics of Zoroastrian philanthropy and the case of Qasr-e Firuzeh', Iranian Studies xlv/1 (2012).

9. Zoroastrian Personal Status was reviewed, amended and agreed at a nationwide conference of the Kankāsh-e Mowbedān-e Tehrān, anjomans and Zoroastrian 
institutions on 27 Ardibehesht 1386/2007. It was passed by the Ministry of Justice on the basis that it did not contravene any laws of the IRI.

10. A popular observance amongst woman whereby the supernatural figure of Shāh Pari is invoked to cure sickness or grant wishes of one sort or another.

11. See Navid Fozi, Reclaiming the Faravahar: Zoroastrian Revival in Contemporary Tehran (Leiden, 2014), pp. 21-2.

12. For more on this relationship see Stausberg-Vevaina, Companion, pp. 183-4.

13. See Fereydun Vahman and Garnik Asatrian, Notes on the Language and Ethnography of the Zoroastrians of Yazd (Copenhagen, 2002), pp. 18-19 where it is noted that the Zoroastrian dialects of Yazd and Kerman are distinct from Persian and derive from the dialects of Central Asia.

14. See Mary Boyce, A Persian Stronghold of Zoroastrianism (London, 1989), pp. 92-138, on 'The Laws and Rites of Purity'.

15. This is a time when people go back to their houses and celebrate with food, music and a gahambar in the fire temple. During the first four days people go from house to house to honour the deceased of each household. At each one the names are read out and dried fruits, apples, oranges and pomegranates are given together with some money, which is collected and goes to the fire temple. On the fifth day everyone gathers at the little fire temple and a gahambar is held.

16. See Michael Fischer and Mehdi Abedi, Debating Muslims: Cultural Dialogues in Postmodernity and Tradition (Wisconsin, 1990), p. 237. For the shrine see http:// www.oshihan.org/Pages/OstadMasterPeer.htm.

17. For a detailed study see S. Kalinock, śsupernatural Intercessions to Earthly Problems: Sofreh Rituals among Shiite Muslims and Zoroastrians in Iran', in Michael Stausberg (ed.), ZoroastrianRituals in Context (Leiden, 2014), pp. 531-47, where she compares Muslim and Zoroastrian practices. Some of these have their counterpart in India, for example the nohud-e moshgel goshā or problem-solving peas.

18. On the Shähnāmeh see the chapter by Ashk Dahlén, Chapter 13 of this volume.

19. The Gabr Mahaleh, as the Zoroastrian quarter was known, was built on ground that had been used for digging clay, which was used for building work and was on a lower grid than the rest of the city. This was designed to ensure that the drainage from the city would flow into the area thereby avoiding the risk of polluting water that Muslims might use. Of course, when it rained people were unable to come out of their houses because of the mud.

20. This is a reference to 'Ali ibn Abi Tàlib, cousin and son-in-law of the Prophet Mohammad, who used a famously double-edged sword, Dhu' l-Fiqār, inherited from Muhammad, to fight against the enemies of Islam. According to Shi'a tradition, after the death of the Prophet, 'Ali never used the sword in campaigns against non-Muslims.

21. According to Mary Boyce by 1962 the last Zoroastrian family moved into the city. Mary Boyce, 'Zoroastrian villages of the Jūpār Range', Festschrift für W. Eilers (Wiesbaden, 1967), p. 149.

22. Michael Fischer, Zoroastrianism in Iran: Between Myth and Praxis (ProQuest Dissertations and Theses, 1973), p. 165. 


\section{REFERENCES}

Boyce, Mary, 'Zoroastrian villages of the Jūpār Range', in Q. Wiessner (ed.), Festschrift für W. Eilers (Wiesbaden, 1967), pp. 148-56.

A Persian Stronghold of Zoroastrianism (London, 1989).

Fischer, Michael, Zoroastrianism in Iran: Between Myth and Praxis (ProQuest Dissertations and Theses, 1973).

Fischer, Michael and Mehdi Abedi, Debating Muslims: Cultural Dialogues in Postmodernity and Tradition (Wisconsin, 1990).

Foltz, Richard, 'Zoroastrians in Iran: What future in the Homeland?', The Middle East Journal lxv/1 (2011), pp. 73-84.

Fozi, Navid, Reclaiming the Faravahar: Zoroastrian Revival in Contemporary Tehran (Leiden, 2014).

Kalinock, S., 'Supernatural Intercessions to Earthly Problems: Sofreh rituals among Shiite Muslims and Zoroastrians in Iran', in Michael Stausberg (ed.), Zoroastrian Rituals in Context (Leiden, 2014), pp. 531-47.

Sansarian, Eliz, Religious Minorities in Iran (Cambridge, 2006).

Stausberg, Michael, 'Zoroastrians in Modern Iran', in M. Stausberg and Yuhan SohrabDinshaw Vevaina (eds), The Wiley Blackwell Companion to Zoroastrianism (Oxford, 2015), pp. 173-90.

Stewart, Sarah, 'The Politics of Zoroastrian Philanthropy and the Case of Qasr-e Firuzeh', Iranian Studies xlv/1 (2012).

Vahman, Fereydun and Garnik Asatrian, Notes on the Language and Ethnography of the Zoroastrians of Yazd (Copenhagen, 2002). 